\title{
Application of an Analog of 9, 10-ketol- octadecadienoic acid (KODA), Affected Flower Bud Formation and MdTFL1 and MdFT1 Gene Expressions in Apple Buds under Heavy-crop and Shade Conditions
}

\author{
Monrudee Kittikorn, Katsuya Okawa, Hitoshi Ohara, and Satoru Kondo ${ }^{1}$ \\ Graduate School of Horticulture, Chiba University, Matsudo 271-8510, Japan \\ Nobuhiro Kotoda and Masato Wada \\ National Institute of Fruit Tree Science, Morioka 020-0123, Japan \\ Mineyuki Yokoyama and Ohji Ifuku \\ Technology and Engineering Center, Shiseido Co., Yokohama 236-8643, Japan
}

Ariake Murata and Naoharu Watanabe

Graduate School of Science and Technology, Shizuoka University, Shizuoka 422-8529, Japan

\begin{abstract}
AdDitional INDEX words. alternate bearing, flowering, gibberellic acid, juvenility, Malus domestica, reproductive phase, vegetative phase

ABstract. Changes of endogenous 9, 10-ketol-octadecadienoic acid (KODA) concentrations, which is synthesized from linolenic acid by 9-lipoxygenase, were analyzed in apple [Malus $\times$ sylvestris (L.) Mill. var. domestica (Borkh.) Mansf.] buds. In addition, the effects of 15, 16-chloro, hydroxy-9-hydroxy-10-oxo-12(Z)-octadecenoic acid (CKODA) application, which is an analog of KODA, on flower bud formation and the expression of MdTFL1 (terminal flower 1) and MdFT1 (flowering locus $t$ ) genes in apple buds were investigated in heavy-crop treatment (HCT) and under shade. An increase of endogenous KODA in the buds in the fruit-thinning treatment, which resulted in a higher proportion of flower bud formation than in HCT, was observed at 63 days after full bloom, but no such increase was found in HCT. In the shade-treated and heavy-crop trees, the expression of MdTFL1 in the buds to which CKODA was applied was lower than that in untreated buds. In contrast, under shade, the expression of MdFT1 in the CKODAtreated buds was higher than that in untreated buds. These results suggest that endogenous KODA may be associated with flower bud formation, and its application may be effective at improving the proportion of flower bud formation through its effect on MdTFL1 and MdFT1.
\end{abstract}

Most fruit trees such as apple trees have a long vegetative period, which is undesirable for growers (Foster et al., 2003; Mimida et al., 2009). In the adult phase, alternate bearing is induced by growing conditions such as heavy fruit load that is associated with gibberellins (Ramirez et al., 2001, 2004). Therefore, the clarification of the physiological mechanism for regulation of flower bud formation is indispensable for stable apple production.

Environmental conditions such as light intensity also influence floral initiation in apple. For instance, low irradiance has been shown to inhibit floral initiation in apical buds of 'Fuji' apple (Kittikorn et al., 2011). The flower inductions of duckweed (Lemna paucicostata L.) and japanese morning glory (Pharbitis nil Choisy) were shown to be associated with KODA levels (Suzuki et al., 2003; Yokoyama et al., 2000). Furthermore, it was shown that endogenous KODA concentrations in apical buds were higher in trees with a higher flower bud formation, and that KODA spraying of one-year-old shoots

Received for publication 21 Dec. 2012. Accepted for publication 4 Feb. 2013 We thank Dr. Haruo Shimada, Shiseido Co., for help in a determination of structure of CKODA used in this work.

${ }^{1}$ Corresponding author. E-mail: s-kondo@faculty.chiba-u.jp. increased the proportion of flower bud formation in trees with normal fruit load [40 leaves per fruit (Kittikorn et al., 2010, 2011)]. These facts show that KODA may be associated with flower bud formation in apple.

Studies on the molecular mechanisms of flowering have been well established in arabidopsis [Arabidopsis thaliana (L.) Heynh. (Bradley et al., 1997)]. Numerous floral meristem identity genes have been isolated from arabidopsis, and several models for the genetic pathways of floral induction and differentiation such as FT, suppressor of constans 1 (SOC1), leafy $(L F Y)$, apetala $1(A P 1)$, and TFL1 have been reported (Henderson and Dean, 2004; Kobayashi et al., 1999; Ratcliffe et al., 1998). Overexpression of $L F Y, F T$, or $A P 1$ has been shown to shorten the vegetative phase, causing early flowering (Kardailsky et al., 1999), whereas overexpression of TFL1 has been shown to cause late flowering in transgenic arabidopsis (Ratcliffe et al., 1998). TFL1 is a key gene involved in repression flowering and maintains the identity of inflorescence meristems by preventing the expression of $A P 1$ and $L F Y$ (Ratcliffe et al., 1998). Arabidopsis plants in which the MdTFL1 gene was transferred showed delayed flowering (Kotoda and Wada, 2005), but 'Orin' apple plants with transferred antisense MdTFL1 RNA flowered after eight months compared with the untreated control 
plants, which took six years to flower. In addition, MdTFL1 was detected in vegetative tissues such as apical buds, stems, and cotyledon, but not in reproductive tissues such as floral organs (sepal, petal, and stamen), suggesting its key role in maintaining the juvenile and/or vegetative phase in apple (Kotoda et al., 2006). Contrary to the functional role of TFL1, FT promoted flowering by altering the expression of other endogenous genes (Esumi et al., 2007; Kardailsky et al., 1999). Invariably, overexpression of $F T$-like genes has led to premature flowering under non-inductive conditions in species such as arabidopsis (Abe et al., 2005), rice [Oriza sativa L. (Tamaki et al., 2007)], tomato [Solanum lycopersicum L. (Lifschitz et al., 2006)], and grape [Vitis vinifera (Carmona et al., 2007)]. KODA application decreased MdTFL1 expression in treated buds (Kittikorn et al., 2011). Therefore, it is possible that KODA application induces flower bud formation in apple through an effect on MdTFL1 transcription. An investigation of the relationship among KODA, $M d T F L 1$, and MdFT1 under various growing conditions may clarify the roles of KODA. However, the effect of KODA application under non-inductive conditions has not been examined.

We have found that CKODA (Fig. 1), an analog of KODA, was more stable than KODA at high temperatures (Kondo et al., 2012). This study examined the effect of CKODA application on the transcription of MdTFL1 and MdFT1 and flower bud formation in apple under heavy cropload and shade conditions.

\section{Materials and Methods}

Plant materials. Experiments were conducted in 2009 and 2010 on 'Fuji' apple trees grafted onto 'Marubakaido' rootstock (Malus prunifolia Borkh. var. ringo Asami) growing in an open field of Chiba University located at lat. $36^{\circ} \mathrm{N}$ and long. $139^{\circ} \mathrm{E}$ at an altitude of $747 \mathrm{~m}$.

EXPT. 1: EFFECT OF CROP LOAD ON THE CHANGES OF ENDOGENOUS KODA. Two groups of three 32-year-old trees (three replications of one tree per each treatment) were created randomly in 2009: one that underwent flower thinning treatment (FTT), in which all flowers were removed at full bloom, and one that underwent HCT, in which the number of leaves per fruit was adjusted to 20 at $20 \mathrm{~d}$ after full bloom (DAFB). At 21, 49, 63, and 103 DAFB, 90 terminal buds from shoot meristems

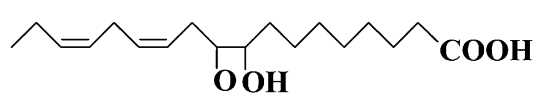

9, 10-ketol-octadecadienoic acid (KODA)

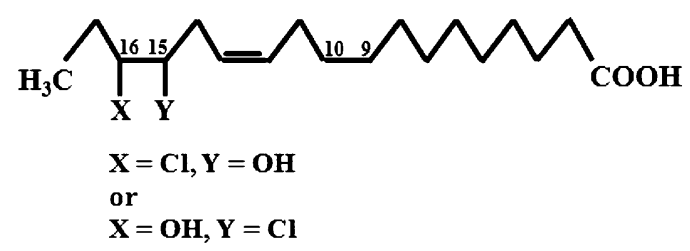

\section{5, 16-chloro, hydroxyl-9-hydroxy-10-oxo-12(Z)-octadecenoic acid (CKODA)}

Fig. 1. Structure of 9, 10-ketol-octadecadienoic acid (KODA) and 15, 16-chloro, hydroxyl-9-hydroxy10-oxo-12(Z)-octadecenoic acid (CKODA). CKODA was formed by introducing a chlorine atom and a hydroxyl group at the $\mathrm{C}-15$ olefin of KODA. (three replications of 30 buds per tree) were randomly collected for analysis of endogenous KODA from each treatment. The sampled buds were from non-fruiting spurs in each treatment.

Analysis of Endogenous KODA. The buds, including whole apical tissues (100 mg fresh weight per 30 buds in one tree from each treatment), were ground in liquid nitrogen and extracted with methanol $(10 \mathrm{~mL})$ using $\left[\mathrm{U}^{13} \mathrm{C}\right] \mathrm{KODA}$ $\left(1 \mathrm{pmol} \cdot \mu \mathrm{L}^{-1}\right)$ as an internal standard at $4{ }^{\circ} \mathrm{C}$. The filtrate was concentrated in vacuo and the concentrates were re-dissolved in methanol $(5 \mathrm{~mL})$ and washed with hexane $(10 \mathrm{~mL})$ to remove pigments. The methanol layer thus obtained was evaporated in vacuo to yield solid materials. The resultant solid materials were re-dissolved in $100 \mu \mathrm{L}$ ethanol, and $5 \mu \mathrm{L}$ of the solution was subjected to high-performance liquid chromatographymass spectrometry (HPLC-MS/MS) (LTQ-Orbitrap Discovery; Thermo Fisher Scientific, Bremen, Germany) equipped with a Capcell Pak C18 UG 120 column $(2 \mathrm{~mm}$ i.d. $\times 7.5 \mathrm{~cm}$; Shiseido, Tokyo, Japan) that was maintained at $4{ }^{\circ} \mathrm{C}$. The samples were analyzed at a flow rate of $0.2 \mathrm{~mL} \cdot \mathrm{min}^{-1}$ using a chromatographic gradient of two mobile phases $(\mathrm{A}=0.05 \%$ aqueous formic acid, $\mathrm{B}=$ acetonitrile). Solvent $\mathrm{B}$ was linearly increased from $15 \%$ to $100 \%$ over $15 \mathrm{~min}$.

The MS conditions were set as follows: ionization mode, electron spray ionization (negative); capillary temperature, $330{ }^{\circ} \mathrm{C}$; capillary voltage, $-27.50 \mathrm{~V}$; collision energy, $35.0 \mathrm{eV}$; and full mass range, $m / z 50$ to $m / z 350 . M^{2}$ values were acquired from a parent ion at $m / z 309[\mathrm{M}-\mathrm{H}]^{-}$for KODA with a scan range of $m / z \quad 85$ to $m / z 310$. The $\mathrm{MS}^{2}$ spectra of $\left[\mathrm{U}-{ }^{13} \mathrm{C}\right]$ KODA were determined based on a selection reaction monitoring an ion at $m / z 327[\mathrm{M}-\mathrm{H}]^{-}$with a scan range of $\mathrm{m} / z 263.5$ to $m / z$ 264.5. [U- ${ }^{13} \mathrm{C}$ ]KODA was eluted at $t_{\mathrm{R}}=10.47 \mathrm{~min}$ with an ion peak at $m / z 327[\mathrm{M}-\mathrm{H}]^{-}$. The $\mathrm{MS}^{2}$ spectrum from the ion at $m / z 327$ exhibited ion peaks at $m / z 309(100 \%)\left[\mathrm{M}-\mathrm{H}_{2} \mathrm{O}\right]^{-}$ and $m / z 264(68.0 \%)\left[\mathrm{M}-\mathrm{H}_{2} \mathrm{O}-\mathrm{H}^{13} \mathrm{COO}\right]^{-}$. The recovery of KODA was estimated based on the ion intensity at $m / z 309$. Similarly, KODA was detected at $t_{\mathrm{R}}=10.40 \mathrm{~min}$ with an ion peak at $m / z$ 309. The $\mathrm{MS}^{2}$ spectrum from the ion at $m / z 309$ showed ion peaks at $m / z 291(100 \%)\left[\mathrm{M}-\mathrm{H}_{2} \mathrm{O}\right.$ ] and $m / z 247$ $(72.3 \%)\left[\mathrm{M}-\mathrm{H}_{2} \mathrm{O}-\mathrm{HCOO}\right]^{-}$. Although 13- $\alpha$-ketol had the same retention time and ion peak at $m / z 309[\mathrm{M}-\mathrm{H}]^{-}$as those of KODA, the $\mathrm{MS}^{2}$ spectrum of $13-\alpha-$ ketol was recorded with ion peaks at $m / z 291(100 \%)$ $\left[\mathrm{M}-\mathrm{H}_{2} \mathrm{O}\right]^{-}$and $m / z 247(3.1 \%)\left[\mathrm{M}-\mathrm{H}_{2} \mathrm{O}-\right.$ $\mathrm{HCOO}^{-}$. Furthermore, the ionization efficacy for $m / z 291$ of 13- $\alpha$-ketol was 3.56 times higher than that of KODA. Quantification of KODA was based on the ion intensities of $\mathrm{m} / \mathrm{z}$ 247 and $m / z 291$ of KODA and 13- $\alpha$-ketol.

EXPT. 2: EFFECT OF CKODA APPLICATION ON THE EXPRESSION OF MDTFL1 AND MDFT1 GENES UNDER HEAVY-CROP AND SHADE CONDITIONS. In the $2010 \mathrm{HCT}$, four 33-year-old trees were randomly selected. The number of leaves per fruit was adjusted to 20 at 20 DAFB as in Expt. 1. One hundred forty one-year-old shoots (560 apical buds in four trees), also randomly selected at $7 \mathrm{DAFB}$, in each tree were sprayed with $100 \mu \mathrm{M}$ CKODA with surfactant $0.1 \%$ (v/v) (New Osmac ${ }^{\circledR}$; Hayashi Chemical, Tokyo, Japan) at 7, 21, 35, and 49 DAFB $\left(\mathrm{HCT}^{+} \mathrm{CKODA}^{+}\right)$. On each day of 
treatment, the tips of the shoots with three nodes were sprayed once until runoff. The untreated controls $\left(\mathrm{HCT}^{+} \mathrm{CKODA}^{-}\right)$were one-year-old shoots that were not sprayed with CKODA. At 7, 21, 35, 49, 63, 77, and 96 DAFB, 90 apical buds (18 buds per each tree) were randomly sampled. Apical buds were frozen immediately in liquid nitrogen and then stored at $-80^{\circ} \mathrm{C}$ until analysis of MdTFL1 and MdFT1 gene expression.

In the shade treatment, three randomly selected 19 -year-old trees were covered with cheesecloth (50\% shading) at 20 DAFB. The number of leaves per fruit was adjusted to 40 at 20 DAFB. This number of leaves per fruit is the usual fruit load not causing alternate bearing. One hundred twenty oneyear-old shoots in each tree (360 apical buds in three trees), also randomly selected at 7 DAFB, were sprayed with $100 \mu \mathrm{M}$ CKODA, like in the crop load experiment ( Shade $^{+} \mathrm{CKODA}^{+}$). At 7, 21, 35, 49, 63, and 77 DAFB, 60 apical buds (20 buds per tree) were randomly sampled for analysis of the expression of MdTFL1 and MdFT1 genes. The untreated controls $\left(\mathrm{Shade}^{+} \mathrm{CKODA}^{-}\right.$) were one-year-old shoots that were not sprayed with CKODA.

To determine the proportion of flower bud formation in the cropload and shade experiments, 90 apical buds (three replications of 30 buds per tree) were randomly collected after defoliation. Each apical bud was longitudinally dissected, and the proportion of flower bud formation was determined with a stereomicroscope. Buds that apical meristems showed to be dome-shaped were counted as flower buds according to a previous report (Kittikorn et al., 2010). The proportion of flower bud formation was calculated by the number of flower buds in 90 apical buds.

Preparation of CKOdA. CKODA $\left(\mathrm{C}_{18} \mathrm{H}_{31} \mathrm{ClO}_{5}\right)$ was formed by introducing a chlorine atom and a hydroxyl group at the C-15 olefin of KODA. KODA (32 mm) of $250 \mathrm{~mL}$ was mixed with $690 \mathrm{~mL}$ distilled water followed by the addition of $60 \mathrm{~mL}$ dilute aqueous solution $[10 \%$ of commercial sodium hypochlorite solution (active chlorine $8.5 \%$ to $13.5 \%$; Nacalai Tesque, Kyoto, Japan)] and vigorously mixed. The conversion rate of CKODA from KODA was more than $60 \%$. CKODA was extracted by ethyl acetate and isolated by HPLC (NANOSPACE SI-1; Shiseido) using an ultraviolet detector at $210 \mathrm{~nm}$ with a Capcell Pak $\mathrm{C}_{18}$ column. The mobile phase was $50 \%$ acetonitrile in $0.05 \%$ trifluoroacetic acid, and the column temperature and flow rate were $30^{\circ} \mathrm{C}$ and $1 \mathrm{~mL} \cdot \mathrm{min}^{-1}$, respectively. The retention time of CKODA was $5.4 \mathrm{~min}$. The product was identified with HPLC-MS/MS. The fragment ions of CKODA were $m / z 363[\mathrm{M}-\mathrm{H}]^{-}$and $345\left[\mathrm{M}-\mathrm{H}-\mathrm{H}_{2} \mathrm{O}\right]^{-}$.

RNA EXTRACTION, CDNA SYNTHESIS, AND QUANTITATIVE REALTIME RT-PCR. Total RNA from apical buds was extracted following the protocol mentioned in a previous report (Kittikorn et al., 2010). DNase treatment (5 units; Takara Bio, Otsu, Japan) at $37{ }^{\circ} \mathrm{C}$ for $20 \mathrm{~min}$ was applied to $2 \mu \mathrm{g}$ of total RNA to eliminate any contaminating DNA in the samples. The reaction was stopped and then incubated at $70{ }^{\circ} \mathrm{C}$ for $10 \mathrm{~min}$. The treated RNA was used as a template for cDNA synthesis. The cDNA was synthesized in a $20-\mu \mathrm{L}$ reaction volume using ReverTraAce (Toyobo, Osaka, Japan) according to the manufacturer's instructions. RNA extraction and cDNA synthesis were repeated twice on each sampling date. The cDNA samples were diluted $(1: 10 \mathrm{v} / \mathrm{v})$ and amplified using the gene-specific primers shown in Table 1. The quantitative reverse transcriptionpolymerase chain reaction (qRT-PCR) was performed using the SYBR master mix (KAPA SYBR ${ }^{\circledR}$ FAST qPCR kit; NIPPON Genetics, Tokyo, Japan) with ABI StepOnePlus (Applied Biosystems, Foster City, CA). The steps involved in amplification were performed as follows: an initial denaturation at $95{ }^{\circ} \mathrm{C}$ for $10 \mathrm{~s}$ followed by 40 cycles of amplification at $95^{\circ} \mathrm{C}$ for $3 \mathrm{~s}$ and annealing at $60{ }^{\circ} \mathrm{C}$ for $32 \mathrm{~s}$. The specificity of the amplification was verified on the basis of a melting curve obtained at the end of the PCR cycle. The relative expression level was normalized to that of the actin gene (Yooyongwech et al., 2008).

Statistical analysis. The SAS analysis of variance procedure (Version 8.02; SAS Institute, Cary, NC) was used to determine the treatment effects, and the mean separation was analyzed by Fisher's least significant difference $(P \leq 0.05)$. The data are presented as the mean values of three replications $\pm \mathrm{SE}$.

\section{Results}

The proportion of flower bud formation of FTT was significantly higher than that of HCT (Table 2). A significant increase in endogenous KODA in FTT was observed at 63 and 103 DAFB, although there was no significant difference of KODA levels at 21 and 49 DAFB between HCT and FTT (Fig. 2). In HCT trees, endogenous KODA levels did not show significant changes from 21 to 103 DAFB.

The relative expression levels of $M d T F L 1$ in $\mathrm{HCT}^{+} \mathrm{CKODA}^{+}$ were significantly lower than those in $\mathrm{HCT}^{+} \mathrm{CKODA}^{-}$at 21, 35, and 49 DAFB (Fig. 3A). In both treatments, the expression of

Table 2. Proportion of flower bud formation in apical buds of 'Fuji' apple treated with 15, 16-chloro, hydroxyl-9-hydroxy-10-oxo12(Z)-octadecenoic acid (CKODA) under heavy-crop treatment (HCT) or shade.

\begin{tabular}{lc}
\hline Treatment & $\begin{array}{c}\text { Proportion of flower bud formation } \\
\text { [mean } \pm \text { SE }(\%)]\end{array}$ \\
\hline $\mathrm{HCT}^{+} \mathrm{CKODA}^{-}$ & $60.3 \pm 0.58^{\mathrm{y}}$ \\
$\mathrm{HCT}^{+} \mathrm{CKODA}^{+}$ & $67.6 \pm 0.60$ \\
$\mathrm{FTT}$ & $81.3 \pm 3.84$ \\
$\mathrm{LSD}_{0.05}$ & 2.30 \\
& $22.0 \pm 2.16$ \\
Shade $^{+} \mathrm{CKODA}^{-}$ & $61.6 \pm 0.74$ \\
$\mathrm{Shade}^{+} \mathrm{CKODA}^{+}$ & 6.35 \\
$\mathrm{LSD}_{0.05}$ &
\end{tabular}

${ }^{\mathrm{z}} \mathrm{HCT}=$ number of leaves per fruit was adjusted to 20 at $20 \mathrm{~d}$ after full bloom (DAFB). Shade $=$ trees covered with cheesecloth $(50 \%$ shading) at $20 \mathrm{DAFB}$; the number of leaves per fruit was adjusted to 40 at 20 DAFB. FTT = flower thinning treatment, in which all flowers were removed at full bloom.

${ }^{\mathrm{y}}$ The proportion of flower bud formation was calculated by the number of flower buds in 90 apical buds. Mean separation was analyzed by Fisher's least significant difference (LSD) $(P \leq 0.05)$. 


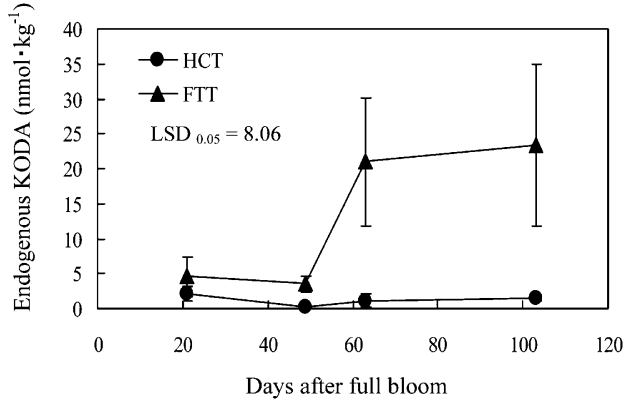

Fig. 2. Changes in endogenous 9, 10-ketol-octadecadienoic acid (KODA) concentrations in the apical buds of 'Fuji' apple subjected to the flower thinning treatment (FTT), in which all flowers were removed at full bloom and heavycrop treatment (HCT), in which the number of leaves per fruit was adjusted to 20 at $20 \mathrm{~d}$ after full bloom. Data are mean \pm SE of three replications.

MdTFL1 decreased sharply after 63 DAFB and leveled off at $77 \mathrm{DAFB}$ in $\mathrm{HCT}^{+} \mathrm{CKODA}^{+}$and $\mathrm{HCT}^{+} \mathrm{CKODA}^{-}$at $98 \mathrm{DAFB}$. The expression patterns of $M d F T 1$ were similar in both CKODAtreated and -untreated buds under HCT conditions, although the times of the increases and decreases differed (Fig. 3B). That is, the expression of $M d F T 1$ in $\mathrm{HCT}^{+} \mathrm{CKODA}^{-}$increased toward $49 \mathrm{DAFB}$ and then decreased at 63 DAFB, whereas that in $\mathrm{HCT}^{+} \mathrm{CKODA}^{+}$increased toward $35 \mathrm{DAFB}$ and then decreased at 49 DAFB. The proportion of flower bud formation in $\mathrm{HCT}^{+} \mathrm{CKODA}^{+}$was significantly higher than that in $\mathrm{HCT}^{+} \mathrm{CKODA}^{-}$(Table 2 ).

In the shade treatment, the application of CKODA significantly increased the proportion of flower bud formation compared with that of untreated control (Table 2). The expression of
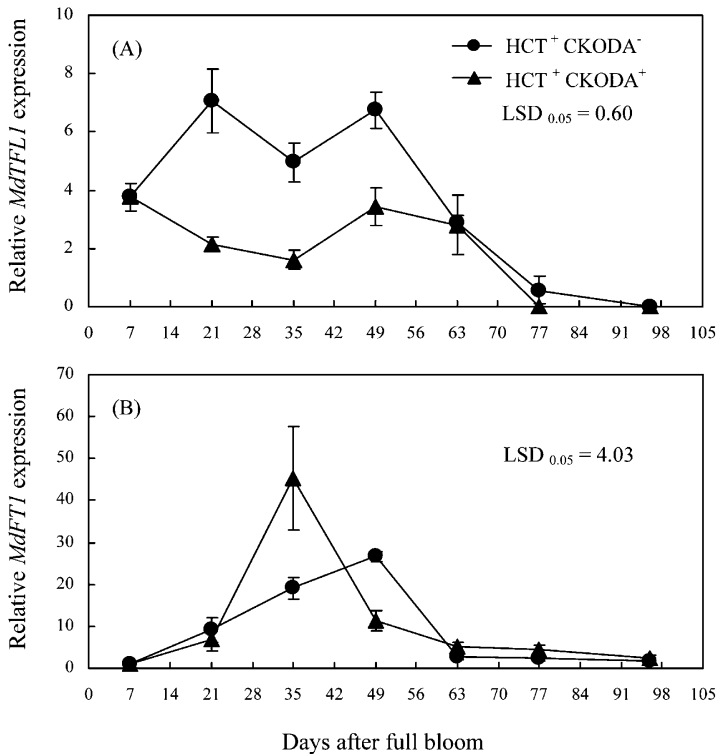

Fig. 3. Quantitative real-time reverse transcription-polymerase chain reaction (RT-PCR) analysis of (A) MdTFL1 and (B) MdFT1 in apical buds of 'Fuji' apple treated with 15, 16-chloro, hydroxyl-9-hydroxy-10-oxo-12(Z)octadecenoic acid (CKODA) under heavy-crop treatment (HCT), in which the number of leaves per fruit was adjusted to 20 at $20 \mathrm{~d}$ after full bloom. The quantitative RT-PCR was performed using the SYBR master mix. The steps involved in amplification were performed as follows: an initial denaturation at $95{ }^{\circ} \mathrm{C}$ for $10 \mathrm{~s}$ followed by 40 cycles of amplification at $95{ }^{\circ} \mathrm{C}$ for $3 \mathrm{~s}$ and annealing at $60{ }^{\circ} \mathrm{C}$ for $32 \mathrm{~s}$. The relative expression level was normalized to that of the actin gene. Data are mean \pm SE of three replications.
MdTFL1 genes at 7, 21, and 35 DAFB did not differ significantly between $\mathrm{Shade}^{+} \mathrm{CKODA}^{+}$and $\mathrm{Shade}^{+} \mathrm{CKODA}^{-}$, but the expression of MdTFL1 in $\mathrm{Shade}^{+} \mathrm{CKODA}^{-}$was higher than that in $\mathrm{Shade}^{+} \mathrm{CKODA}^{+}$at 49, 63, and 77 DAFB (Fig. 4A). In contrast, the expression in $\mathrm{Shade}^{+} \mathrm{CKODA}^{+}$did not show much change.

In general, the patterns of change of MdFT1 expression in both CKODA-treated and -untreated buds were similar under shade conditions (Fig. 4B). The MdFT1 expressions increased toward 35 DAFB and then decreased at 49 DAFB. However, the expressions of MdFT1 in $\mathrm{Shade}^{+} \mathrm{CKODA}^{+}$were significantly higher than those in Shade $^{+} \mathrm{CKODA}^{-}$.

\section{Discussion}

In a previous report, we reported the changes of endogenous KODA in apple buds with 15-hydroxypentadecanoic acid as the internal standard using a fluorescence detector in HPLC (Kittikorn et al., 2010). In the current study, endogenous KODA was analyzed using liquid chromatography-MS/MS for more accurate determination. The endogenous KODA concentrations in FTT were significantly higher than those of HCT. Furthermore, these concentrations increased significantly at 63 DAFB and before flower bud formation, as shown in a previous report (Kittikorn et al., 2010). This fact suggests that endogenous KODA may play a positive role in flower bud formation in apple. Either endogenous gibberellins (GAs) from the seeds or GA spray is known to inhibit flowering in apple (Ramirez et al., 2001, 2004). Therefore, it is possible that low endogenous KODA concentrations in the buds of HCT are associated with
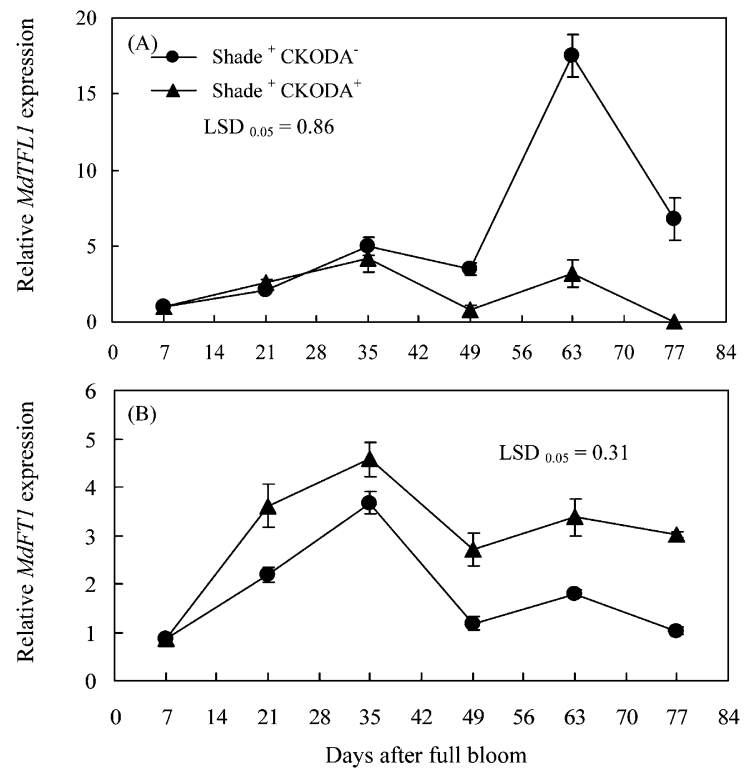

Fig. 4. Quantitative real-time reverse transcription-polymerase chain reaction (RT-PCR) analysis of (A) MdTFL1 and (B) MdFT1 in apical buds of 'Fuji' apple treated with 15, 16-chloro, hydroxyl-9-hydroxy-10-oxo-12(Z)octadecenoic acid (CKODA) under shade, in which the trees were covered with cheesecloth ( $50 \%$ shading) at $20 \mathrm{~d}$ after full bloom (DAFB). The number of leaves per fruit was adjusted to 40 at 20 DAFB. The quantitative RT-PCR was performed using the SYBR master mix. The steps involved in amplification were performed as follows: an initial denaturation at $95{ }^{\circ} \mathrm{C}$ for $10 \mathrm{~s}$ followed by 40 cycles of amplification at $95^{\circ} \mathrm{C}$ for $3 \mathrm{~s}$ and annealing at $60{ }^{\circ} \mathrm{C}$ for $32 \mathrm{~s}$. The relative expression level was normalized to that of the actin gene. Data are mean $\pm \mathrm{SE}$ of three replications. 
high GA concentrations compared with those in FTT (Kittikorn et al., 2010). However, KODA application to the buds did not influence endogenous GA concentrations in the buds (Kittikorn et al., 2011). Therefore, the relationship between auxin and cytokinin, which influence flower bud formation (Sanyal and Bangerth, 1998), and KODA should also be examined. In addition, the origin of endogenous KODA in the buds of apple requires further investigation.

It has been shown that FT and TFL1 homologs are important in regulating the flowering time and maintaining the inflorescence meristem in several plant species (Hanke et al., 2007). A homolog of the FT and TFL1 gene family has been isolated and characterized in fruit trees such as apple (Kotoda and Wada, 2005; Kotoda et al., 2006), grape (Carmona et al., 2007), sweet orange [Citrus sinensis L. Osbeck (Pillitteri et al., 2004)], and pear and quince [Pyrus pyrifolia Nakai and Cydonia oblonga Mill. (Esumi et al., 2005)]. MdTFL1 gene in apple, which is a TFL1-like gene, functions equivalently to TFL1 expressed constitutively in transgenic arabidopsis plants, suggesting that it has the potential to complement the TFL1 function (Kotoda et al., 2006). It could function redundantly as a flowering repressor and a regulator of vegetative meristem identity because MdTFL1 is detected strongly in vegetative tissues (Mimida et al., 2009). Our previous report (Kittikorn et al., 2011) showed that the accumulation of MdTFL1 mRNA transcript levels was found in buds under both heavy-crop and shade treatments that related to the decrease of flower bud formation. The proportion of flower bud formation in apical buds of apple increased after 70 DAFB (Kittikorn et al., 2010). In our study, CKODA application in HCT decreased MdTFL1 mRNA transcript levels at 21,35, and 49 DAFB, although the expression of MdTFL1 in $\mathrm{HCT}^{+} \mathrm{CKODA}^{-}$decreased sharply after 63 DAFB. It has been shown that MdTFL1 mRNA was expressed strongly in June, which is 7 weeks after full bloom, which occurs 1 to 2 weeks after the initiation of floral bud formation; from June, the expression decreased gradually toward late July (Kotoda and Wada, 2005). In our study, the proportion of flower bud formation in $\mathrm{Shade}^{+} \mathrm{CKODA}^{-}$was lower than that in $\mathrm{HCT}^{+} \mathrm{CKODA}^{-}$. In addition, the expression of MdTFL1 in $\mathrm{Shade}^{+} \mathrm{CKODA}^{-}$was higher than that in $\mathrm{HCT}^{+} \mathrm{CKODA}^{-}$at 63 DAFB. Although the MdTFL1 expression in Shade $^{+} \mathrm{CKODA}^{-}$decreased at $77 \mathrm{DAFB}$, the expression level was significantly higher than that of Shade ${ }^{+} \mathrm{CKODA}^{+}$. These results support that the induction of flower bud formation and floral development may be coincident with the interruption of MdTFL1 expression (Kotoda and Wada, 2005; Mimida et al., 2009). Furthermore, MdTFL1 expression in our study shows that low light intensity may have a more negative effect on flower bud formation than a heavy cropload.

Contrary to the functional role of TFL1, FT promoted flowering by altering the expression of other endogenous genes (Esumi et al., 2007; Kardailsky et al., 1999). The mobile FT protein has been identified as a main component of the florigen or flowering hormone in arabidopsis, tomato, and rice (Lifschitz et al., 2006; Turck et al., 2008; Zeevaart, 2008). In apple, MdFT1 and MdFT2 genes have been isolated and their functions clarified (Kotoda and Wada, 2005; Kotoda et al., 2010). A transgenic experiment revealed that both MdFT1 and MdFT2 had the potential to function as floral promoters in apple. However, the transcriptional activation of $M d F T 1$ is more closely associated with the regulation of flower induction in apple than that of MdFT2. Therefore, we examined the transcription level of MdFT1. In our study, the expression of MdFT1 in $\mathrm{HCT}^{+} \mathrm{CKODA}^{+}$reached a peak earlier and higher than in $\mathrm{HCT}^{+} \mathrm{CKODA}^{-}$. It has been reported that the increase of MdFT1 (Hättasch et al., 2009; Kotoda et al., 2010) and AFL1 and AFL2 transcription levels (apple orthologs of $L F Y$ ) (Wada et al., 2002) in the apical meristems of one-year-old apple shoots began 1 to 2 weeks earlier than flower initiation. In our study, MdFT1 expression levels in $\mathrm{HCT}^{+} \mathrm{CKODA}^{-}$were higher than

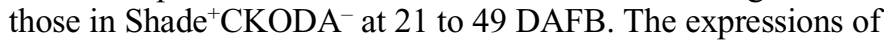
MdFT1 were increased earlier by CKODA application in both HCT and shade treatment. The increase of the proportion of flower bud formation at 70 DAFB (Kittikorn et al., 2010), which did not occur after the increase of MdFT1 but did occur after the decrease of $M d T F L 1$ expression, suggests that the role of $M d T F L 1$ may be downstream of MdFT1. It was demonstrated that the dynamic state of MdFT1 and MdTFL1 genes observed in our study may be associated with flower bud formation.

In summary, endogenous KODA in the buds of trees in which the proportion of flower bud formation was high increased before the initiation of flower bud formation. In heavycrop and shade-treated trees, the application of CKODA, a derivative of KODA, increased the proportion of flower bud formation and the expression of MdFT1 but decreased the expression of MdTFL1.

\section{Literature Cited}

Abe, M., Y. Kobayashi, S. Yamamoto, Y. Daimon, A. Yamaguchi, and Y. Ikeda. 2005. FD, a bZIP protein mediating signals from the floral pathway integrator FT at the shoot apex. Science 309:10521056.

Bradley, D., O. Ratcliffe, C. Vincent, R. Carpenter, and E. Coen. 1997. Inflorescence commitment and architecture in arabidopsis. Science 275:80-83.

Carmona, M.J., M. Calonje, and J.M. Martínez-Zapater. 2007. The FT/TFL1 gene family in grapevine. Plant Mol. Biol. 63:637-650.

Esumi, T., R. Tao, and K. Yonemori. 2005. Isolation of leafy and terminal flower 1 homologues from six fruit tree species in the subfamily maloideae of the rosaceae. Sex. Plant Reprod. 17:277-287.

Esumi, T., R. Tao, and K. Yonemori. 2007. Relationship between floral development and transcription levels of the leafy and termanal flower 1 homologs in japanese pear (Pyrus pyrifolia Nakai) and quince (Cydonia oblonga Mill.). J. Jpn. Soc. Hort. Sci. 76:294-304.

Foster, T., R. Johnston, and A. Seleznyova. 2003. A morphological and quantitative characterization of early floral development in apple (Malus $\times$ domestica Borkh.). Ann. Bot. (Lond.) 92:199-206.

Hanke, M.V., H. Flachowsky, A. Peil, and C. Hättasch. 2007. No flower no fruit-Genetic potentials to trigger flowering in fruit trees. Genes Genomes Genomics 1:1-20.

Hättasch, C., H. Flachowsky, M.V. Hanke, S. Lehmann, A. Gau, and D. Kapturska. 2009. The switch to flowering: Genes involved in floral induction of the apple 'Pinova' and the role of the flowering gene MdFT. Acta Hort. 839:701-705.

Henderson, I.R. and C. Dean. 2004. Control of arabidopsis flowering: The chill before the bloom. Development 131:3829-3838.

Kardailsky, I., V.K. Shukla, J.H. Ahn, N. Dagenais, S.K. Christensen, J.T. Nguyen, J. Chory, M.J. Harrison, and D. Weigel. 1999. Activation tagging of the floral inducer FT. Science 286:1962-1965.

Kittikorn, M., K. Okawa, H. Ohara, N. Kotoda, M. Wada, M. Yokoyama, O. Ifuku, and S. Kondo. 2011. Effect of fruit load, shading, and 9, 10ketol-octadecadienoic acid (KODA) application on MdTFL1 and MdFT1 genes in apple buds. Plant Growth Regulat. 64:75-81.

Kittikorn, M., N. Shiraishi, K. Okawa, H. Ohara, M. Yokoyama, O. Ifuku, S. Yoshida, and S. Kondo. 2010. Effect of fruit load on 9, 10-ketol-octadecadienoic acid (KODA), GA and jasmonic acid concentration in apple buds. Sci. Hort. 124:225-230. 
Kobayashi, Y., H. Kaya, K. Goto, M. Iwabuchi, and T. Araki. 1999. A pair of related genes with antagonistic roles in mediating flowering signals. Science 286:1960-1962.

Kondo, S., H. Tomiyama, M. Kittikorn, K. Okawa, H. Ohara, M. Yokoyama, O. Ifuku, T. Saito, Y. Ban, M. Tatsuki, T. Moriguchi, A. Murata, and N. Watanabe. 2012. Ethylene production and 1-aminocyclopropane-1-carboxylate (ACC) synthase and ACC oxidase gene expression in apple fruit are affected by 9, 10-ketoloctadecadienoic acid (KODA). Postharvest Biol. Technol. 72:20-26.

Kotoda, N., H. Hayashi, M. Suzuki, M. Igarashi, Y. Hatsuyama, S. Kidou, T. Igasaki, M. Nishiguchi, K. Yano, T. Shimizu, S. Takahashi, H. Iwanami, S. Moriya, and K. Abe. 2010. Molecular characterization of flowering locus $t$-like genes of apple (Malus $\times$ domestica Borkh.). Plant Cell Physiol. 51:561-575.

Kotoda, N., H. Iwanami, S. Takahashi, and K. Abe. 2006. Antisense expression of MdTFL1, a TFL1-like gene, reduces the juvenile phase in apple. J. Amer. Soc. Hort. Sci. 131:74-81.

Kotoda, N. and M. Wada. 2005. MdTFL1, a TFL1-like gene of apple, retards the transition from the vegetative to reproductive phase in transgenic arabidopsis. Plant Sci. 168:95-104.

Lifschitz, E., T. Eviatar, A. Rozman, A. Shalit, A. Goldshmidt, and Z. Amsellem. 2006. The tomato FT ortholog triggers systemic signals that regulate growth and flowering and substitute for diverse environmental stimuli. Proc. Natl. Acad. Sci. USA 103:6398-6403.

Mimida, N., N. Kotoda, T. Ueda, M. Igarashi, Y. Hatsuyama, H. Iwanami, S. Moriya, and K. Abe. 2009. Four TFL1/CEN-like genes on distinct linkage groups show different expression patterns to regulate vegetative and reproductive development in apple (Malus $\times$ domestica Borkh.). Plant Cell Physiol. 50:394-412.

Pillitteri, L.J., C.J. Lovatt, and L.L. Walling. 2004. Isolation and characterization of a terminal flower homolog and its correlation with juvenility in citrus. Plant Physiol. 135:1540-1551.

Ramirez, H., G.V. Hoad, A. Benavides, and E. Rangel. 2001. Gibberellins in apple seeds and the transport of $\left[{ }^{3} \mathrm{H}\right]-\mathrm{GA}_{4}$. J. Mexican Chem. Soc. 45:47-50.
Ramirez, H., J. Torres, A. Benavides, J. Hernandes, and V. Robledo. 2004. Fruit bud initiation in apple cv Red Delicious linked to gibberellins and cytokinins. J. Mexican Chem. Soc. 48:7-10.

Ratcliffe, O.J., I. Amaya, C.A. Vincent, S. Rothstein, R. Carpenter, E.S. Coen, and D.J. Bradley. 1998. A common mechanism controls the life cycle and architecture of plants. Development 125:1609-1615.

Sanyal, D. and F. Bangerth. 1998. Stress induced ethylene evolution and its possible relationship to auxin-transport, cytokinin levels, and flower bud induction in shoots of apple seedlings and bearing apple trees. Plant Growth Regulat. 24:127-134.

Suzuki, M., S. Yamaguchi, T. Iida, I. Hashimoto, H. Teranishi, M. Mizoguchi, F. Yano, Y. Todoroki, N. Watanabe, and M. Yokoyama. 2003. Endogenous $\alpha$-ketol linolenic acid levels in short day-induced cotyledons are closely related to flower induction in Pharbitis nil. Plant Cell Physiol. 44:35-43.

Tamaki, S., S. Matsuo, H.L. Wong, S. Yukoi, and K. Shimamoto. 2007. Hd3a protein is a mobile flowering signal in rice. Science 316:1033-1036.

Turck, F., F. Fornara, and G. Coupland. 2008. Regulation and identity of florigen: flowering locus $t$ moves center stage. Annu. Rev. Plant Biol. 59:573-594.

Wada, M., Q. Cao, N. Kotoda, J. Soejima, and T. Masuda. 2002. Apple has two orthologues of floricaula/leafy involved in flowering. Plant Mol. Biol. 49:567-577.

Yokoyama, M., S. Yamaguchi, S. Inomata, K. Komatsu, S. Yoshida, T. Iida, Y. Yokokawa, M. Yamaguchi, S. Kaihara, and A. Takimoto. 2000. Stress-induced factor involved in flower formation of lemna is an $\alpha$-ketol derivative of linolenic acid. Plant Cell Physiol. 41:110-113.

Yooyongwech, S., A.K. Horigane, M. Yoshida, M. Yamaguchi, Y. Sekozawa, S. Sugaya, and H. Gemma. 2008. Changes in aquaporin gene expression and magnetic resonance imaging of water status in peach tree flower buds during dormancy. Physiol. Plant. 134:522523.

Zeevaart, J.A. 2008. Leaf-produced floral signals. Curr. Opin. Plant Biol. 11:541-547. 